\title{
The Effect of Different Indigenous Processing Methods on the Chemical Composition of Cassava Products
}

\author{
Lilian Aburime $^{1} \quad$ Ugochukwu Okereke $^{2} \quad$ Ebele Nzekwe $^{2}$ \\ 1-2.Department of Biochemistry (Nutrition and Dietetic unit) University of Calabar, Calabar, Cross River State \\ Nigeria \\ 3. National Institute for Hospitality and Tourism (NIHOTOUR), Enugu, Enugu State Nigeria
}

\begin{abstract}
The research is financed by the authors
\end{abstract}
\section{Abstract}

Effective processing and knowledge of the food composition of indigenous staples are imperative for optimal benefit from the nutritive value of food products. This study investigates the effect of different processing methods on the chemical composition of cassava productsBitter variety of cassava was harvested from a farm in Akpabuyo Local Government Area of Cross River state, Nigeria. The raw bitter cassava roots were peeled and divided into five equal parts of about $500 \mathrm{~g}$ each. They were processed into garri, "fufu", dry "abacha" wet "abacha", and cassava starch. The "garri" was produced by grating, fermenting ( $72 \mathrm{hrs})$, sieving and toasting the raw cassava. Cassava starch was produced by fermenting the raw cassava at room temperature $\left(31^{\circ} \mathrm{C}\right)$ in a root water ratio of about $1: 3 \mathrm{w} / \mathrm{v}$ for 5 days. The "Fufu" was prepared by boiling moulded cassava starch in water for 15 min. After which it was pounded. Wet "abacha" was produced by cutting $(10 \mathrm{~cm})$ and boiling the cassava roots for about $25 \mathrm{mins}$. After which it was sliced into jardinière shape of about $3 \times 3 \times 18 \mathrm{~mm}$ batons and soaked for 8 hours. Dry "abacha" was produced by shredding the boiled (25mins) raw cassava and sun drying it for 5 days. The products were dried using a food dehydrator $\left(40^{\circ} \mathrm{C}^{)}\right.$and stored in an airtight container for chemical analysis. The products were analyzed using standard AOAC laboratory methods. Data were analyzed using Statistical Package for the Social Sciences. Mean and standard deviations were calculated and significance accepted at $p<0.05$. The results of the proximate composition of the products were as follows; moisture (13.2 -65.1\%), Ash (0.2 -0.5\%), Fat (0.3$0.9 \%)$, Dietary fibre (1.2 - 4.3\%), protein (0.6-1.6\%) and available carbohydrate $(32.1-81 \%)$. The Energy contents of the samples ranged from $688 \mathrm{KJ}$ in dry "fufu" to $1451 \mathrm{KJ}$ in dry "abacha". "Garri" had the highest calcium $(20 \mathrm{mg} / 100 \mathrm{~g})$, phosphorus $(56 \mathrm{mg} / 100 \mathrm{~g})$, potassium $(222 \mathrm{mg} / 100 \mathrm{~g})$ and sodium $(7 \mathrm{mg} / 100 \mathrm{~g})$ contents. The raw starch had the highest magnesium content of $10 \mathrm{mg} / 100 \mathrm{~g}$. The percentage contributions of the products to the recommended nutrient intake (RNI) of adults were as follows: "fufu" had the highest contribution of phosphorus (10\%). Sodium $(0.1-0.4 \%)$, potassium (1-6mg \%) and magnesium (1-4\%) contributions were generally low in all the products. The Protein $(1-3 \%)$ and fat $(0.5 \%-1 \%)$ contributions to the RNI were low but that of carbohydrate was high and ranged from $30 \%$ in "fufu" to $62 \%$ in "dry "abacha". "Garri" had the highest contribution of dietary fibre (17\%). Dry "abacha" and "garri" had the highest energy contributions of $17 \%$ to the RNI of adults. All the cassava products had low levels of hydrogen cyanide which ranged from $3.42 \mathrm{mg} / 100 \mathrm{~g}$ in "garri" to $7.57 \mathrm{mg} / 100 \mathrm{~g}$ in "fufu". The traditional processing used for processing raw bitter cassava into dry "abacha" is shown to be insufficient in reducing the HCN to a safe level of $<50 \mathrm{mg} / \mathrm{kg}$ so further processing is recommended. Knowledge of the chemical composition of cassava products will enable consumers to make informed food choices for better nutrition and health outcome.

Keywords: Cassava, traditional processing, Hydrogen cyanide, proximate and mineral composition

DOI: $10.7176 / \mathrm{JBAH} / 9-12-05$

Publication date: June $30^{\text {th }} 2019$

\section{Introduction}

Cassava, (Manihot esculenta) is a root and tuber crop. It has the capability of meeting year-round production because of its ability to survive in poor soils, high yield per hectare of land and good resistance to pest infestations, diseases and drought. Cassava is a very important food crop in Africa and ranks third in importance after rice and corn. Nigeria is the world highest cassava producer and about $84 \%$ of the cassava produced is consumed (FAO, 2014). The versatility of cassava plant is such that every part is useful. In Nigeria, the leaves can be used as vegetables in soups and sauces. The stem can be propagated and the roots can be fermented, boiled and used for variable products like "garri", "fufu", wet "abacha", dry "abacha", starch, "alibo" among others. Food and nutrition insecurity can be eradicated if an indigenous staple like cassava is well processed and utilized. Nigeria has been cited as one of the countries with food insecurity (Otaha, 2013). About 3.7 million Nigerians are food insecure (FAO, IFAD, UNICEF, WFP \& WHO, 2018). Using indigenous foods will improve food security (FAO, 2012b). In Nigeria, cassava processing is still at the household level for small to medium-sized production (FAO, 2004). Knowledge of the nutrient composition of processed cassava using household equipment is important. Generally, cassava on wet weight basis contains about $70-80 \%$ moisture, carbohydrates (which are mainly starches) is about $16-24 \%$, protein $0-2 \%$ and fat $0-2 \%$. The utilization of Cassava roots and leaves is limited by cyanogenic 
glycosides (linamarin \& lotaustralin) which are decomposed by linamarase to liberate hydrogen cyanide (HCN). $\mathrm{HCN}$ being a volatile compound can easily evaporate at a temperature of $28^{\circ} \mathrm{C}$ or above. It dissolves rapidly in water. HCN can also be destroyed during the transportation of the food material or its storage. Hydrogen cyanide in cassava can be reduced by crushing, drying, soaking and fermentation among others (Cardoso et al., 2005). Variety, environmental conditions like drought and the time of harvest influences the HCN level of cassava. Appropriate processing is required to reduce or eliminate these harmful secondary metabolites of cassava. Traditionally, cassava product is fermented to produce "garri" and starch for "fufu" production; it is further cooked and pounded to obtain "fufu". Raw cassava roots are boiled, sliced and soaked to produce wet "abacha". They are also boiled, shredded and dried to produce dry "abacha". Even though raw cassava is processed into variable products, limited data is available on the chemical composition of the processed samples. This research work seeks to assess the effect of processing on the chemical composition of different cassava products.

\section{Materials and methods}

The bitter raw cassava used for this study was freshly harvested from a farm in Akpabuyo Local Government Area, Cross River State, Nigeria in the month of October. The raw bitter cassava roots were divided into five (5) equal parts of about $5 \mathrm{~kg}$ each and processed into "garri", "fufu", "wet abacha", "dried abacha" and starch.

"Garri"

Bitter cassava roots were sorted, peeled and washed with tap water. The sample was grated using a $10 \mathrm{~mm}$ size grater, the grated sample was packed in a sack and pressed in a jack for three (3) days (72hours) for it to ferment. After fermentation, the mass was sieved using an iron sieve of about $0.1 \mathrm{~mm}$. The sieved sample was toasted in a deep-frying pan until it became dry and brittle; it was allowed to cool, packaged and stored in a zip lock bag for laboratory analysis.

\subsection{Cassava starch}

The cassava roots were sorted to select wholesome roots without rot or damage. The sorted samples were manually peeled, washed, and cut into small sizes of about $5 \mathrm{~cm}$ using a kitchen knife. The sample was then soaked with tap water for five days to undergo fermentation. After fermentation, the water was discarded and the soft roots were taken out and sieved manually using an iron sieve of about $0.5 \mathrm{~mm}$. The filtrate was allowed to sediment in a large plastic bowl. After sedimentation, the mash was put into a jute bag and squeezed tightly to expel the excess water for about 48hours.

\section{2 "Fufu"}

"Fufu" was made from the starch by moulding it into desired shape and placing into boiling water; it was allowed to boil for fifteen (15) minutes after which it was pounded. After pounding, it was moulded and put back into boiling water for another ten (10) minutes. After 10 minutes, the cassava balls were pounded again until it became off white in colour.

\subsection{Wet "Abacha"}

The conventional method of preparing "Wet Abacha" was used. The cassava roots were peeled and cut into small size of about $10 \mathrm{~cm}$, followed by washing with tap water. The washed samples were boiled for twenty (25) minutes and cooled. After cooling, it was cut into jardinière shape of about $3 \times 3 \times 18 \mathrm{~mm}$ batons using a knife. The piece was then rinsed thoroughly with tap water and soaked in water for 8hour. After which water was drained and prepared for chemical analysis

\subsection{Dried "abacha"}

"Dry Abacha" was prepared using a conventional method. The cassava roots were peeled and cut into small sizes of 7 inches length and washed with water. The washed sample was boiled for twenty (25) minutes and allowed to cool. After cooling, it was shredded into julienne shape of about $10 \mathrm{~cm}$ using a locally made grater. The shredded product was then washed gently with water, drained and thinly spread on a tray and sun-dried for five days.

\subsection{Preparation of samples for analysis}

The raw cassava starch, "fufu" and wet "abacha" were dehydrated using a food dehydrator $\left(40^{\circ} \mathrm{C}\right)$ for $48 \mathrm{hrs}$. After dehydration, they were milled separately into fine flours. "Garri" and dried "abacha" were also milled to fine flour and stored for chemical analysis.

\subsection{Proximate Composition}

The methods described by the Association of Official Analytical Chemist (AOAC, 2012) were used in determining moisture, ash, total fat and crude protein content of the samples. Dietary fibre was carried out by Prosky, Asp, Furda, DeVries, Schweizer and Harland, (1985) method as described by AOAC Method 985.29. Available 
carbohydrate was determined by difference.

The energy value of the products was calculated using the Atwater factor.

\subsubsection{Determination of Moisture Content}

Two grams $(2 \mathrm{~g})$ of the sample was weighed into a previously weighed crucible. The crucible plus the sample was taken and transferred into the oven set at 100 degree Celsius to dry to constant weight for 24 hours. The crucible plus the sample was removed from the oven, cooled for 10 minutes and reweighed. The sample in the crucible was returned into the oven for further drying. The drying cooling and weighted was done at an interval of 4hours until a constant weight was obtained. The moisture content was calculated as a percentage of the ratio of moisture loss to the weight of the samples analyzed.

The expression represented below was used in the calculation:

$\mathrm{X} 1=$ weight of empty crucible

$\mathrm{X} 2$ = weight of empty crucible + sample

$\mathrm{X} 3=$ weight of empty crucible + dry sample

Percentage $(\%)$ moisture $=\underline{\mathrm{X} 2-\mathrm{X} 3 \times 100}$

\subsubsection{Determination of Ash Content}

Total ash content was determined as total inorganic matter by incineration of a sample at $600^{\circ} \mathrm{C}(\mathrm{AOAC}, 2012)$. Sample $(2 \mathrm{~g})$ was weighed into a pre-weighed porcelain crucible and incinerated overnight in a muffle furnace at $600^{\circ} \mathrm{C}$. The crucible was removed from the muffle furnace, cooled in desiccator and weighed. Ash content was calculated according to the following formula:

$$
\% \text { ash content }=\frac{\text { weight of ash }}{\text { Weight of sample }} \times \frac{100}{1}
$$

\subsubsection{Dietary fibre}

This was carried out by Prosky, Asp, Furda, DeVries, Schweizer and Harland, (1985) method as described by AOAC Method 985.29. After ashing, $5 \mathrm{~g}$ of dried and defatted food samples were subjected to sequential enzymatic digestion by heat-stable bacterial $\alpha$-amylase in harsh conditions $\left(\mathrm{pH} 8.2,100^{\circ} \mathrm{C}\right)$ to give gelatinization, hydrolysis and depolymerization of starch and protein for the enzymatic incubation step. The samples were precipitated following the addition of ethanol. The precipitated samples were filtered and weighed. Total dietary fibre was then determined by subtracting the weight of protein and ash from the weight of the precipitate.

\subsubsection{Determination of Crude Fat}

Crude fat was estimated by employing solvent extraction using a Soxhlet extraction unit (AOAC, 2012)

About $1 \mathrm{~g}$ of the sample were weighed and placed in a thimble. Some $120 \mathrm{ml}$ petroleum ether was poured into a previously dried and weighed round bottom flask. The Soxhlet extractor apparatus was set up with the flask and the condenser. The extraction apparatus was set up with the flask sitting on the spaces provided on the hot plate. The hot plate was plugged and set to gentle heating, the other evaporated and as it condensed, it dropped into the thimble where it extracted the other soluble constituents (fat constituent) into the flask. The colour deepens as time increases. The experiment was allowed to run for about 6 hours. The thimble was then removed and dried in the oven (later the fat-free sample was used for fibre content determination). The petroleum ether in the flask was evaporated off. The flask was then dried in an air circulating desiccator. The round bottom flask and the lipid extract were then weighed. The flask and its content were dried again to obtain constant weight. Amount of lipid was obtained from the difference between the weight of the flask before extraction and after extraction. Crude fat was calculated using the formula:

$\%$ crude fat $=\frac{\text { weight of extract }}{\text { Weight of sample }} \times \frac{100}{1}$

\subsubsection{Determination of Crude Protein}

The method used in the determination of protein content was the micro Kjeldahl method described by (AOAC, 2012).

About $1 \mathrm{~g}$ of the sample powder was weighed out into $50 \mathrm{ml} \mathrm{Kjeldahl} \mathrm{digestion} \mathrm{flask.} \mathrm{Some} 20 \mathrm{ml}$ concentrated $\mathrm{H}_{2} \mathrm{SO}_{4}, 1$ tablet of Kjeldahl catalyst and anti-bombing chips were added. The mixture was incinerated to gentle boiling on the digestion rack and then heated or a further 3 hours. The digest was removed, cooled, quantitatively transferred to a $100 \mathrm{ml}$ volumetric flask and made up to mark. Erlenmeyer flask containing $10 \mathrm{ml}$ of the boric acidindicator solution was placed at the tip of the condenser extended below the surface of the solution. About $10 \mathrm{ml}$ of the sample digest was introduced into the sample tube and steam heated, $10 \mathrm{ml}$ of $40 \% \mathrm{NaOH}$ solution was added to the digest and the digest was steamed and distilled into the boric acid-indicator solution, it changed to green. A blank determination was also carried out alongside that of the sample except that $1 \mathrm{~g}$ sample was replaced with $1 \mathrm{ml}$ distilled water. The crude protein content is calculated as follows:

$\%$ protein $=\mathrm{ml} \mathrm{HCl}($ test $)-\mathrm{ml} \mathrm{HCl}($ blank $) \times$ normality of acid $\times 1.4 \times 100 \times 6.25 \times 100$

$100 \times 10 \times 0.1$ 


\section{Calculation of available carbohydrate Content}

The available carbohydrate content of the samples was calculated by eliminating the percentage of the other food nutrients. Mathematically, Available Carbohydrate $=100-($ crude protein + lipid + ash + moisture + dietary fibre $)$.

\subsubsection{Determination of Caloric Value}

The caloric (KJ) value of the samples was obtained by multiplying the mean values of the crude protein, lipid, available Carbohydrate and dietary fibre by 17, 37, 17 and 8 respectively (Atwater factor) and taking the sum of the products.

\subsubsection{Determination of Mineral Contents}

The mineral elements were determined using wet-acid digestion method for multiple nutrients determination. The digest was used for the determination of Calcium $(\mathrm{Ca})$ by the EDTA Versanate Complexometric titration method, Potassium $(\mathrm{k})$ and Sodium $(\mathrm{Na})$ by the flame photometry method, phosphorus $(\mathrm{P})$ by the Vanadomolybdate yellow method, using the spectrometer and Magnesium $(\mathrm{Mg})$ by the Atomic Absorption Spectrophotometry.

\subsubsection{Determination of Calcium}

Calcium $(\mathrm{Ca})$ was determined by the EDTA Versanate Complex metric titration method. 10ml of the aliquot of the digest was pipetted into a conical flask, and then a pinch of potassium cyanide and potassium ferrocyanide were added to the digest to mask the interference of other ions during the determination.

\subsubsection{Determination of Potassium (K) and Sodium (Na)}

Potassium $(\mathrm{K})$ and Sodium $(\mathrm{Na})$ were determined by the flame photometry method. $5 \mathrm{ml}$ of the sample digest was pipette into a $50 \mathrm{ml}$ volumetric flask and diluted to $50 \mathrm{ml}$ with distilled water. A set of Potassium (K) and Sodium (Na) was prepared to contain 0ppm, 2ppm, 4ppm, 6ppm, 8pppm and 10ppm of the element in the solution.

The flame photometer was placed on a sealed calibrated with $6 \mathrm{ppm}$ and adjusted to 60 . The standard solution was tested and their values recorded, the appropriate filter (photocell) was selected for each element. The atomizer of the instrument was dipped into the sample solution and the meter reading taken. The values obtained from the standard were used to plot the calibration curve for each test mineral element and the concentration of the sample element determined by extrapolating from the graph as ppm off the curve.

\subsubsection{Determination of Phosphorus (P)}

Phosphorus was determined using the vanado-molybdate spectrophotometric method. $5 \mathrm{ml}$ of the extract was pipetted into a $500 \mathrm{ml}$ volumetric flask. About $10 \mathrm{ml}$ of distilled water was added initially to the $10 \mathrm{ml}$ of the vanado reagent. The sample was allowed for about 45 minutes for complete colour development and the absorbance (optical density) measured in a UNICAM UV/ULS spectrophotometer at 400nm wavelength.

A set of phosphorus working standards was prepared in a $50 \mathrm{ml}$ volumetric flask which contains $0 \mathrm{ppm}, 2 \mathrm{ppm}$, 4ppm, 6ppm, 8pppm and 10ppm of phosphorus. The same experiment as done for the samples were also carried out on the standards. The values obtained were used to plot standard curve for the extrapolation of the sample values as ppm.

\section{Results}

Table 1 presents the energy $(\mathrm{KJ})$ and Proximate composition of raw cassava and the processed products (\% wet weight basis* as consumed **). Energy ranged from 592KJ in wet "abacha" to $1451 \mathrm{KJ}$ in dry "abacha". There were wide variations in the moisture contents and it ranged from $13.2 \%$ in "garri" and dry "abacha" to $65.1 \%$ in wet "abacha". In contrast to the moisture contents, ash contents were similar and ranged from $0.2 \%$ in wet "abacha" and "fufu" to $0.5 \%$ in "garri" and dry "abacha". The fat contents of the samples were also similar. Starch had the highest content of $0.9 \%$, while wet "abacha' had the lowest fat content of $0.3 \%$. "garri" had the highest dietary fibre content of $4.3 \%$ while "wet "abacha" had the lowest value of $1.2 \%$. Protein ranged from $0.6 \%$ in "fufu" and wet "abacha" to $1.6 \%$ in "garri". Carbohydrate was highest $(81 \%)$ in dry "abacha" and lowest $(32.6 \%)$ in wet "abacha

Table 2 presents the mineral composition of raw cassava and the processed products $(\mathrm{mg} / 100 \mathrm{~g})$ (as consumed *, wet weight basis**). Calcium ranged from $4 \mathrm{mg} / 100 \mathrm{~g}$ in dry "abacha" to $20 \mathrm{mg} / 100 \mathrm{~g}$ in "garri". It was significantly different $(\mathrm{P}<0.05)$ from the value of $16 \mathrm{mg} / 100 \mathrm{~g}$ obtained for raw cassava. Magnesium ranged from $4 \mathrm{mg} / 100 \mathrm{~g}$ in wet "abacha" to $10 \mathrm{mg} / 100 \mathrm{~g}$ in starch. Magnesium was highest $(\mathrm{P}<0.05)$ in starch $(10 \mathrm{mg} / 100 \mathrm{~g})$ and lowest in wet "abacha" (4mg/100g). Phosphorus and potassium were highest $(25 \mathrm{mg} / 100 \mathrm{~g}$ and $222 \mathrm{mg} / 100 \mathrm{~g}$ respectively) in "garri" and also lowest $(13 \mathrm{mg} / 100 \mathrm{~g}$ and $38 \mathrm{mg} / 100 \mathrm{~g}$ respectively) in wet "abacha". "Garri" also had the highest sodium content of $7 \mathrm{mg} / 100 \mathrm{~g}$, while starch had the lowest value of $1 \mathrm{mg} / 100 \mathrm{~g}$.

Table 3 presents the percentage contributions of $100 \mathrm{~g}$ of products to the recommended nutrient intakes (RNI) of adults. The products contributions to the RNI of calcium ranged from $1 \%$ in "fufu", wet "abacha" and dry "abacha" to $3 \%$ in "garri and starch. "Fufu" had the highest (10\%) contribution to the RNI of phosphorus, while wet and dry "abacha had the least (3\%). The products contributions to the RNI of sodium ranged from $0.1 \%$ in "fufu" and wet "abacha" to $0.4 \%$ in "garri". "garri" and dry "abacha" had the highest $(6 \%)$ contribution to the RNI of potassium while wet "abacha" had the least contribution of $1 \%$. The contributions of the products to the RNI of magnesium ranged from $1 \%$ in wet "abacha" to $4 \%$ in "fufu" and "garri". The product contributions to the RNI of 
protein follow a similar trend with calcium; it ranged from $1 \%$ in "fufu" and wet "abacha" to $3 \%$ in "garri" and dry "abacha". "Garri" and dry "abacha" contributed $1 \%$ and $17 \%$ of the RNI of fat and energy (KJ) respectively, while wet "abacha" contributed the least values of $0.5 \%$ and $7 \%$ respectively. " Garri" similarly, contributed the highest value of $17 \%$ to the RNI of dietary fibre while "fufu" and wet "abacha" contributed the least value of $5 \%$.

Table 4 presents the hydrogen cyanide composition of raw cassava and the processed products $(\mathrm{mg} / 100 \mathrm{~g})(\mathrm{as}$ consumed *, wet weight basis**).

"Garri" (3.42mg/100g) and "fufu" $(3.48 \mathrm{mg} / 100 \mathrm{~g})$ had similar hydrogen cyanide level which was significantly $(\mathrm{P}<0.05)$ lower than the level found in Wet "abacha" $(4.67 \mathrm{mg} / 100 \mathrm{~g})$, dry "abacha" $(7.57 \mathrm{mg} / 100 \mathrm{~g})$ and starch $(4.60 \mathrm{mg} / 100 \mathrm{~g})$.

\section{Discussion}

The moisture level observed in "garri" and dry "abacha" indicates they might not keep for a long time. This is because a moisture level of $12 \%$ is termed suitable for the storage of "garri" (Codex standard, 2013). The low ash contents of all the processed samples indicate low mineral contents (Popov, Posokhov, Rachev \& Zaostrovskii, 2015). The value of ash observed from this study contradicts that observed by Oresegun \& Fagbenro,Ilona \& Bernard (2016). The fat contents of the samples show that they are not good sources of fat since the fat contents are below 3g/100g (Dietetics Association of Australia (DAA), 2019). The higher dietary fibre contents of the "garri" and dry "abacha" might be attributed to their lower moisture contents when compared to other products from this study. The low protein content in all the products is not surprising as several studies have equally cited cassava and its products as poor sources of protein (FAO, 2014). The observed carbohydrate level of the products is in line with several studies which indicated that cassava is a good source of carbohydrate especially starch (FAO, 2004, Adepoju, Adekola, Mustapha \& Ogunola, 2010). The calcium, phosphorus, potassium and sodium contents of the products were generally low and were below $3 \%$ of the recommended nutrient intake (RNI). This finding is similar to that of Salvador, Steenkamp \& McCrindle (2014) that reported lower levels of these minerals. The significant reduction in the level of hydrogen cyanide can be attributed to the processing. The greatest reduction in the "fufu" and "garri" can be attributed to fermentation. Fermentation is known to significantly reduce several toxic substances in legumes (Maphosa \& Jideani, 2017; Adegbehingbe, Fakoya \& Adeleke, 2017). The greater reduction of hydrogen cyanide in wet "abacha", "garri", "fufu" and starch makes these products safe for consumption as the HCN contents are within the stipulated safe level of less than $50 \mathrm{mg} / \mathrm{kg}$, on the other hand, dry "abacha" had higher level and might not be safe for consumption (Guédé, Traoré \& Brou, 2013).

\section{Conclusion}

The nutrient compositions of the products from bitter cassava variety showed that "garri" had substantial contributions to the RNI of dietary fibre. The products generally had low contents of calcium, potassium, sodium and magnesium but "garri" and "fufu" had substantial amount of phosphorus as it contributed 10\% of the RNI. The contributions of the products to the RNI for carbohydrates was high. Traditional processing like fermentation, cooking and sun drying used for the production of "garri', starch, "fufu" wet and dry "ábacha" is imperative for the reduction of hydrogen cyanide. Greater reduction of HCN was more in the fermented products than other products. The reductions for "garri", "fufu", wet "abacha" and starch were all within the safe level of less than $50 \mathrm{mg} / \mathrm{kg}$ stipulated for $\mathrm{HCN}$ in foods, but the reduction in dry "abacha" was higher than this range, therefore dry "abacha" might need to be processed further in order to reduce the HCN to safe level.

\section{References}

Guédé, S.S., Traoré, S \& Brou, K (2013). Assessment of Cyanide Content in Cassava (Manihot esculenta Crantz). Varieties and derived Products from Senegal. International Journal of Nutrition and Food Sciences, 2 (9)5, $225-231$

Adegbehingbe, K.T., Fakoya, S \& Adeleke, B.S (2017). Effect of Fermentation on Nutrient and Antinutrient Contents of Fermented Whole and Ground African Breadfruit (Treculia africana) Seeds, Microbiology, 20(5):1-11.

Maphosa, Y \& Jideani, V.A (2017). The Role of Legumes in Human Nutrition, Functional Food - Improve Health through Adequate Food, Maria Chavarria Hueda, IntechOpen, DOI: 10.5772/intechopen.69127. Available from: https://www.intechopen.com/books/functional-food-improve-health-through-adequate-food/the-roleof-legumes-in-human-nutrition.

Adepoju, O. T., Adekola, Y.G., Mustapha, S.O \& Ogunola, S.I (2010), Effect of processing methods on nutrient retention and contribution of cassava to nutrient intake of Nigerian consumers. African Journal of Food Agriculture, Nutrition and Development. 10 (2); 2099-2111.

Salvador, E. M., Steenkamp, V \& McCrindle, C. M. E (2014). Production, consumption and nutritional value of cassava (Manihot esculenta, Crantz) in Mozambique: An overview. Journal of Agricultural Biotechnology and Sustainable Development, 6(3), 29-38. 
Dietetics Association of Australia (DAA) (2019). What does low fat mean? Retrieved from https://daa.asn.au/smart-eating-for-you/smart-eating-fast-facts/food-labels/what-does-low-fat-mean/.

Cardoso, A.R., E. Mirone, M. Ernest, F. Massza and J. Cliff et al., 2005. Modification of nutritional quality of cassava through plant nutrition. J. Food Compos. Anal., 18: 451-461.

Codex standard (2013). Codex standard for "garri”. CODEX STAN 151-1989.

FAO (2004). The global cassava development strategy food: A cassava industrial revolution in Nigeria The potential for a new industrial crop International Fund for Agricultural Development. Food and Agriculture Organization of the United Nations Rome, 2004. http://www.fao.org/3/y5548e/y5548e00.htm\#Contents

Association of Official Analytical Chemists (AOAC) (2012). Official method of analysis. $19^{\text {th }}$ edition, Washington D.C.

FAO (2014). Food outlook biannual report on global food markets. Food and Agriculture Organization of the United Nations.

FAO, IFAD, UNICEF, WFP and WHO (2018). The State of Food Security and Nutrition in the World 2018. Building climate resilience for food security and nutrition. Rome, FAO.License: CC BY-NC-SA 3.0 IGO.

FAO. (2012b). The state of food insecurity in the world: economic growth is necessary but not sufficient to accelerate the reduction of hunger and malnutrition. Rome, Italy.

Otaha, I.J (2013). Food Insecurity in Nigeria: Way Forward. African Research Review, 7 (4),26-35

Table 1: Energy (KJ/Kcal) and Proximate Composition of the processed cassava products (\% wet weight basis* as consumed **)

\begin{tabular}{|c|c|c|c|c|c|c|c|c|}
\hline Samples & $\begin{array}{l}\text { Energy } \\
(\text { Kcal/KJ) }\end{array}$ & Moisture & Ash & Fat & $\begin{array}{l}\text { Dietary } \\
\text { Fibre }\end{array}$ & Protei & & $\begin{array}{l}\text { Av. } \\
\text { Carbohydrate }\end{array}$ \\
\hline "Garri” ** & 1441 & $13.2 \pm 0.00$ & $\begin{array}{l}0.5 \pm \\
0.00\end{array}$ & $\begin{array}{l}0.7 \pm \\
0.02\end{array}$ & $4.3 \pm 0.02$ & $\begin{array}{l}1.6 \\
0.11\end{array}$ & \pm & $79.7 \pm 0.10$ \\
\hline "Fufu” ** & 688 & $\begin{array}{l}59.1 \\
0.13\end{array}$ & $\begin{array}{l}0.2 \pm \\
0.57\end{array}$ & $\begin{array}{l}0.4 \pm \\
0.10\end{array}$ & $1.3 \pm 0.01$ & $\begin{array}{l}0.6 \\
0.62\end{array}$ & \pm & $38.4 \pm 0.62$ \\
\hline $\begin{array}{l}\text { Wet } \\
\text { "Abacha"** }\end{array}$ & $592 \mathrm{~g}$ & $\begin{array}{l}65 . \quad 1 \quad \pm \\
0.08\end{array}$ & $\begin{array}{l}0.2 \pm \\
0.57\end{array}$ & $\begin{array}{l}0.3 \pm \\
0.15\end{array}$ & $1.2 \pm 0.01$ & $\begin{array}{l}0.6 \\
0.06\end{array}$ & \pm & $32.6 \pm 0.37$ \\
\hline $\begin{array}{l}\text { Dry } \\
\text { "Abacha"** }\end{array}$ & 1451 & $\begin{array}{l}13.2 \\
0.01\end{array}$ & $\begin{array}{l}0.5 \pm \\
0.00\end{array}$ & $\begin{array}{l}0.7 \\
0.25\end{array}$ & $3.3 \pm 0.01$ & $\begin{array}{l}1.3 \\
0.28\end{array}$ & \pm & $81.0 \pm 0.53$ \\
\hline Starch* & 819 & $\begin{array}{l}50.2 \\
0.01\end{array}$ & $\begin{array}{l}0.3 \pm \\
0.05\end{array}$ & $\begin{array}{l}0.9 \pm \\
0.00\end{array}$ & $2.6 \pm 0.05$ & $\begin{array}{c}1.5 \\
0.06\end{array}$ & \pm & $43.5 \pm 0.06$ \\
\hline
\end{tabular}

Table 2: Mineral Composition of raw and processed cassava products $(\mathbf{m g} / \mathbf{1 0 0 g})$ (as consumed *, wet** weight basis)

\begin{tabular}{llllll}
\hline Samples & Calcium & Magnesium & Phosphorus & Potassium & Sodium \\
\hline Raw cassava** & $16 \pm 0.17^{\mathrm{c}}$ & $8 \pm 0.94^{\mathrm{b}}$ & $43 \pm 5.78^{\mathrm{b}}$ & $176 \pm 0.30^{\mathrm{c}}$ & $13 \pm 0.34^{\mathrm{a}}$ \\
"Garri"* & $20 \pm 1.5^{\mathrm{a}}$ & $7 \pm 0.57^{\mathrm{c}}$ & $56 \pm 5.82^{\mathrm{a}}$ & $222 \pm 0.85^{\mathrm{a}}$ & $7 \pm 1.04^{\mathrm{b}}$ \\
"Fufu"** & $10 \pm 0.57^{\mathrm{d}}$ & $8 \pm 0.04^{\mathrm{b}}$ & $14 \pm 0.21^{\mathrm{d}}$ & $56 \pm 1.31^{\mathrm{e}}$ & $1.8 \pm 0.04^{\mathrm{d}}$ \\
Wet "abacha"** & $9 \pm 0.05^{\mathrm{d}}$ & $4 \pm 0.62^{\mathrm{d}}$ & $13 \pm 0.43^{\mathrm{d}}$ & $38 \pm 0.45^{\mathrm{f}}$ & $2.3 \pm 0.0^{\mathrm{d}}$ \\
Dry "abacha"* & $4 \pm 0.28^{\mathrm{e}}$ & $6 \pm 0.57^{\mathrm{c}}$ & $53 \pm 5.6^{\mathrm{a}}$ & $199 \pm 1.05^{\mathrm{b}}$ & $4.8 \pm 0.76^{\mathrm{c}}$ \\
ST* $^{*}$ & $19 \pm 0.56^{\mathrm{b}}$ & $10 \pm 1.42^{\mathrm{a}}$ & $17 \pm 0.51^{\mathrm{c}}$ & $140 \pm 1.06^{\mathrm{d}}$ & $1.0 \pm 0.04^{\mathrm{d}}$ \\
\hline
\end{tabular}


Table 3: Percentage contributions of $100 \mathrm{~g}$ of products to the recommended macronutrient and mineral intake of Adults

\begin{tabular}{|c|c|c|c|c|c|}
\hline Variables & RNI & "garri" & "Fufu" & Wet "abacha" & Dry "abacha" \\
\hline $\mathrm{Ca}(\mathrm{mg} / \mathrm{day})$ & 700 & 3 & 1 & 1 & 1 \\
\hline Phosphorus(mg/day) adults & 550 & 9 & 10 & 3 & 3 \\
\hline Sodium(mg/day) & 1600 & 0.4 & 0.1 & 0.1 & 0.3 \\
\hline Potassium(mg/day) & 3500 & 6 & 2 & 1 & 6 \\
\hline \multicolumn{6}{|l|}{$\operatorname{Mg}(\mathrm{mg} /$ day $)$} \\
\hline Male19-65 & 260 & 3 & 3 & 1 & 2 \\
\hline female19-65 & 220 & 3 & 4 & 2 & 3 \\
\hline males $65+$ & 224 & 3 & 4 & 2 & 3 \\
\hline female $65+$ & 190 & 4 & 4 & 2 & 3 \\
\hline Protein $(\mathrm{g})(\mathrm{F})$ & 46 & 3 & 1 & 1 & 3 \\
\hline (M) & 56 & 3 & 1 & 1 & 3 \\
\hline Fat & 65 & 1 & 0.6 & 0.5 & 1 \\
\hline Carbohydrate & 130 & 61 & 30 & 25 & 62 \\
\hline \multirow[t]{2}{*}{ Dietary fibre } & $25(\mathrm{M})$ & 17 & 5 & 5 & 13 \\
\hline & $38(\mathrm{~F})$ & 11 & 3 & 3 & 9 \\
\hline Energy & 8400 & 17 & 8 & 7 & 17 \\
\hline
\end{tabular}

Table 4

Hydrogen Cyanide Composition of raw and processed cassava (mg/100g) (wet weight basis)

\begin{tabular}{ll}
\hline Samples & Cyanide \\
"Garri" & $3.42 \pm 0.07^{\mathrm{d}}$ \\
"Fufu" & $3.48 \pm 0.02^{\mathrm{d}}$ \\
WA & $4.67 \pm 0.03^{\mathrm{c}}$ \\
DA & $7.57 \pm 0.04^{\mathrm{b}}$ \\
ST & $4.60 \pm 0.06^{\mathrm{c}}$ \\
\hline
\end{tabular}

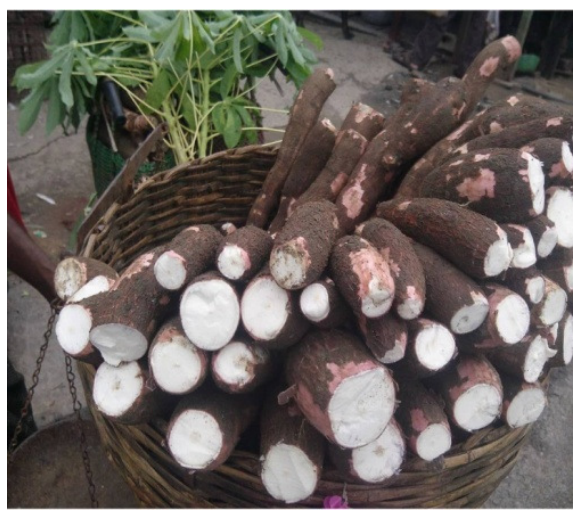

Plate 1: raw bitter cassava

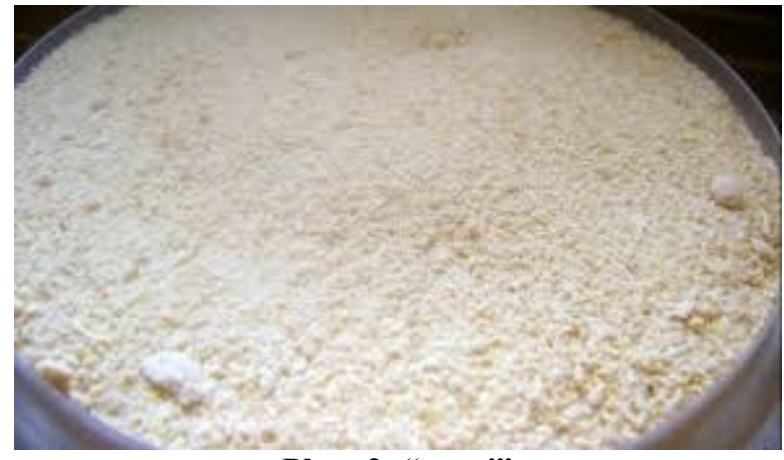

Plate 2: "garri" 


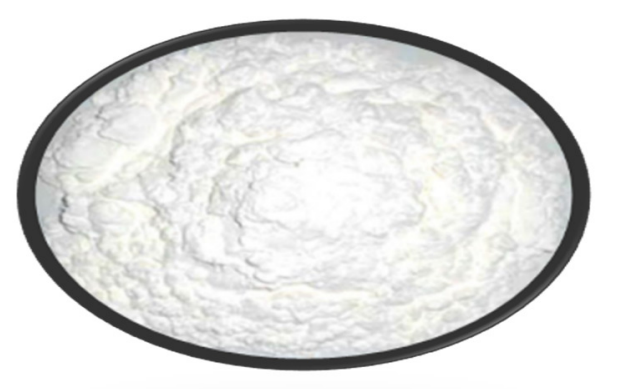

Plate 3: cassava starch

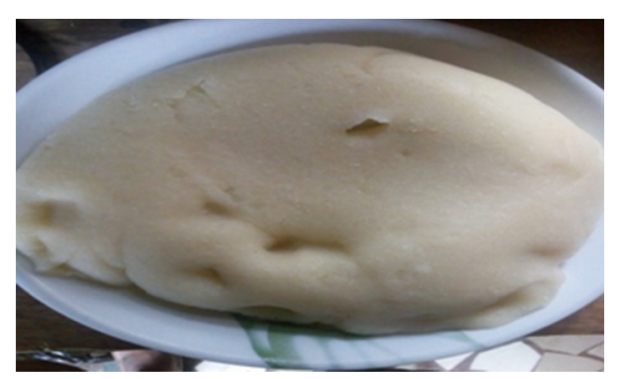

Plate 4: "fufu"

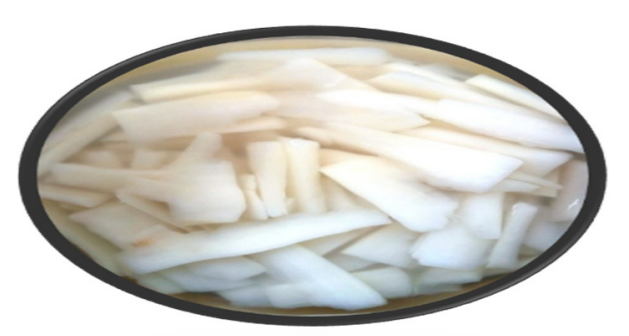

Plate 5: wet "abacha"

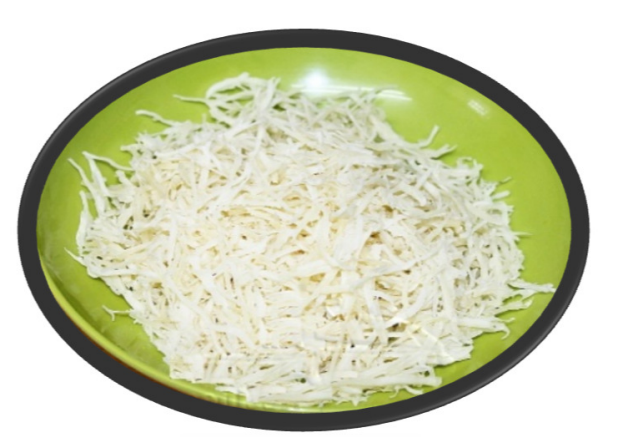

Plate 6: Dry "abacha" 